\title{
A comprehensive approach for the assessment of shared aquifers: the case of Mexico City
}

\author{
Sandra Martinez ${ }^{1} \cdot$ Oscar Escolero $^{1} \cdot$ Maria Perevochtchikova $^{2}$
}

Received: 20 May 2015/Accepted: 20 June 2015/Published online: 17 July 2015

(C) Springer International Publishing 2015

\begin{abstract}
Mexico City depends heavily on shared aquifers; more than $72 \%$ of the water supply is pumped from four aquifers shared by neighboring states. The overlap in competition between federal and local management agencies and the lack of coordination and planning at different levels inhibit efforts toward regional management of this highly demanded resource. An approach integrating the concepts of uses-problems and policy life cycle, with the driving force-pressure-state-impact-response framework was applied to identify key issues and select indicators tailored to the local problems. The issues were analyzed and developed into the components, describing the causality chain from driving forces to impacts and response. Thus, variables grouped into driving forces, pressures, states, impacts and responses were identified, which can be used as indicators for assessment and management of shared aquifers. The proposed structure seems to be appropriate to harmonize information needs and indicators, and to support cooperation between agencies in charge of management and development of the shared aquifers supplying Mexico City.
\end{abstract}

Keywords Groundwater management - Transboundary aquifer - Overabstraction · Water supply $\cdot$ Sustainability indicators

Sandra Martinez

seddam2002@yahoo.com.mx

1 Departamento de Geología Regional, Instituto de Geología, Universidad Nacional Autónoma de México, Ciudad Universitaria, Coyoacan, 04510 Mexico City, Mexico

2 Centro de Estudios Demográficos, Urbanos y Ambientales, El Colegio de México AC, Camino al Ajusco No. 20, Pedregal de Sta. Teresa, 10740 Mexico City, Mexico

\section{Introduction}

Groundwater extraction has grown rapidly in the past decades, especially in developing countries. This phenomenon is evident in Mexico City, where more than $70 \%$ of the total water supply comes from four aquifer systems shared by four neighboring states. Groundwater extraction in the last 60 years has caused a decline in the water level and land subsidence as a consequence. In recent years, water quality, rather than quantity, has become a concern in some areas of the country.

Both the federal and local governments are responsible for development and management of the water supply system in Mexico City, and they themselves recognize the aquifers are being overexploited. Control measures are being implemented to reduce the negative impacts and, although they have had some success at the local scale, the same problems keep appearing at new sites.

The complexity of the water supply system in Mexico City, and the overlap in competition between federal and local authorities constrain efforts toward regional management of the water resources; however, this also leads to the development of innovative management approaches (Sophocleous 2010). Such approaches should include implementation of management measures from the perspective of shared water resources and the exchange of information between different agencies facing common problems.

Indicators are increasingly being developed and used as management tools for different purposes (Ojeda-Martınez et al. 2009; Godfrey et al. 2002; Karageorgis et al. 2006). In Mexico, a system of indicators was developed to evaluate the performance of national environmental policy in the context of sustainable development, incorporating water quantity and quality issues (SEMARNAT 2000; 
Rodríguez-Ortega and Flores-Martínez 2009). Despite Mexicós heavy dependence on groundwater, this resource is seldom taken into consideration when developing indicators.

Initiatives of UNESCO's International Hydrological Programme (IHP) phases, FAO, IAEA and UNEP as well as professional organizations such as the International Association of Hydrogeologists (IAH) have produced important methodological guidelines to develop groundwater indicators (UN/ECE 1999, 2000; UNESCO 2007). Groundwater indicators simplify the information collected in monitoring and assessment programs, help determine the current status and future trends of the systems, and support the analysis of natural processes and human impacts in space and time. Indicators are a useful tool for managers and policy makers because they allow evaluating the response of the system to implemented measures and aid to develop new actions.

In this work, a comprehensive methodological approach is applied to identify, discuss and define the key issues and the related variables which can be potentially used as indicators to support sustainable management of shared aquifers supplying Mexico City. This approach provides a way to reach agreement on key issues affecting shared groundwater resources and develop relevant indicators, and supports cooperation between agencies to meet the water management challenges of the future.

\section{Water supply in Mexico City}

Mexico City, established as Federal District (Distrito Federal, DF) by the Mexican Constitution, is located in the southwestern part of the Valley of Mexico, $2240 \mathrm{~m}$ above mean sea level (masl), and is enclosed by mountains that reach 5500 masl. With a population of approximately 8.85 million, the region faces the lowest per capita water availability estimated at $74 \mathrm{~m}^{3} /$ year (CONAGUA 2009).

The water supply system in Mexico City includes (Fig. 1): (1) transfer of surface water from basins located in the states of Mexico and Michoacán by means of the Cutzamala system, (2) transfer of groundwater from well fields located on aquifers shared by the states of Mexico, Michoacán, Hidalgo and DF (Chiconautla, PAI and Lerma systems), (3) groundwater extraction from wells in Mexico City (SACM wells), and (4) uptake of springs that outcrop in Sierra del Ajusco, a mountain chain located to the south of Mexico City. In this paper, only the systems extracting groundwater will be discussed (Table 1). The aquifers names and limits have been established and published in official decrees by the National Water Commission (Comisión Nacional del Agua, CONAGUA).
Starting in the 1930s, a large number of wells were drilled in the Mexico City Metropolitan Zone (Zona Metropolitana de Ciudad de México, ZMCM) aquifer, underlying Mexico City and the State of Mexico. Today a total of 549 wells completed to depths between 30 and $1300 \mathrm{~m}$ in Mexico City provide a flow estimated at $14 \mathrm{~m}^{3} / \mathrm{s}$. This system, identified as the Mexico City Water System Wells (Sistema de Agua de la Ciudad de México, SACM) represents the main source of water to the city.

The Lerma system was developed to bring water from the upper Lerma basin, situated in the neighboring State of Mexico. Built between 1940 and 1960, the Lerma system now provides a flow estimated at $7.8 \mathrm{~m}^{3} / \mathrm{s}$ by means of 250 active wells connected to aqueducts serving Mexico City. These wells were drilled to depths varying between 60 and $400 \mathrm{~m}$ in the aquifers of Valle de Toluca, in the State of Mexico, and Ixtlahuaca-Atlacomulco, in the states of México and Michoacán, which provide 70 and $30 \%$ of the extracted volume, respectively.

In response to city growth, additional wells were drilled in other neighboring states to increase the water supply. Since 1957, the Chiconaultla System, located $32 \mathrm{~km}$ north of the city, conducts water from 41 wells drilled in the Cuautitlan-Pachuca aquifer underlying the Mexico and Hidalgo states. These wells extend to depths between 50 and $320 \mathrm{~m}$, and currently provide an estimated flow of $1.3 \mathrm{~m}^{3} / \mathrm{s}$.

The system called Immediate Action Wells (Pozos de Acción Inmediata, PAI) was constructed in 1974, as a temporary solution to the city's water supply problem. This system provides $2.6 \mathrm{~m}^{3} / \mathrm{s}$ from 204 wells drilled into the ZMCM aquifer and the Cuautitlán-Pachuca aquifer, underlying the DF and the states of Mexico and Hidalgo.

Thus, the groundwater component of the water supply system in Mexico City comprises four political entities: DF, and the states of Mexico, Michoacán and Hidalgo (Table 1). The CONAGUA manages these shared aquifers, mainly through their regional office called Waters of the Valley of Mexico Basin Authority (Organismo de Cuenca Aguas del Valle de Mexico, OCAVM), which is also involved in systems' operation. However, the agency primarily in charge of operation is the Mexico City Water System (Sistema de Agua de la Ciudad de Mexico, SACM).

\section{Methodological approach}

An approach integrating the concepts of uses-problems and policy life cycle, with the DPSIR (driving force-pressurestate-impact-response) framework was applied in this study (Fig. 2). The approach proposed by UN/ECE (2000) for monitoring and assessment of transboundary 


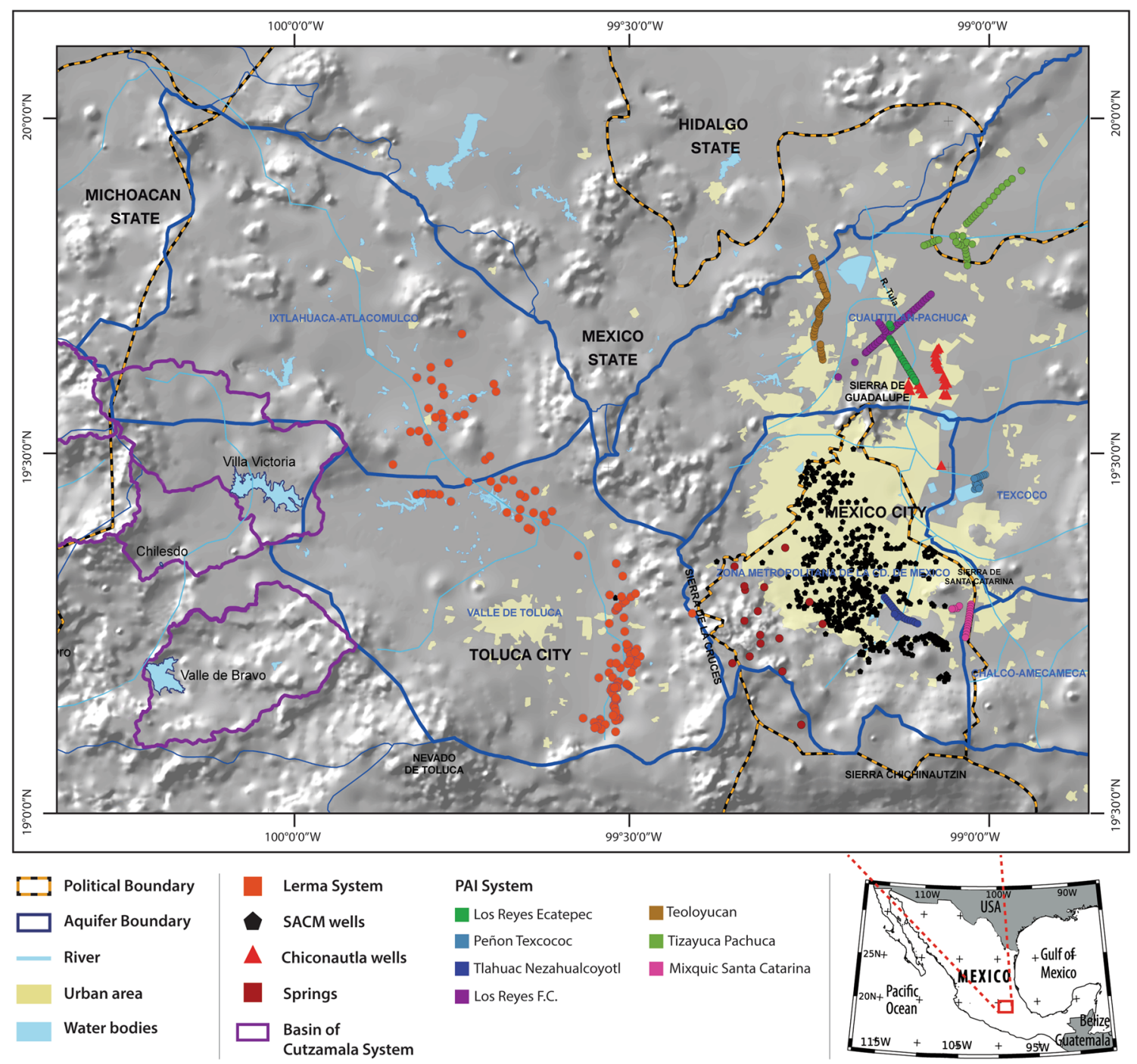

Fig. 1 Location of aquifers and the drinking water supply systems of Mexico City

Table 1 Water supply systems of Mexico City and management structure

\begin{tabular}{lllll}
\hline Supply system & Exploited aquifer & State & System operation responsible & Resource management responsible \\
\hline SACM Wells & ZMCM & DF and Mexico & SACM & OCAVM-CONAGUA \\
Lerma & Ixtlahuaca-Atlacomulco & Mexico and Michoacan & SACM & CONAGUA \\
& Valle de Toluca & Mexico & & OCAVM-CONAGUA \\
Chiconaulta & Cuautitlan-Pachuca & Mexico and Hidalgo & SACM & OCAVM-CONAGUA \\
PAI & ZMCM & DF and Mexico & SACM/OCAVM & \\
& Cuautitlan-Pachuca & Mexico and Hidalgo & & \\
\hline
\end{tabular}

groundwater was used to explore different management aspects of the aquifers shared locally by Mexico City and to recommend indicators tailored to the local needs as a management tool.

As a first step, the core issues defined by the use (or function) of groundwater and the problems that affect it were identified. Using official data and reports furnished by the water authority and local water providers, the predominant use and the problems in relation to this use were identified, which in turn permitted highlighting the potential conflicts in water management.

The level of recognition of these issues achieved in the policy life defines to some extent the management stage. The issues identified in this first step are recognized by the 


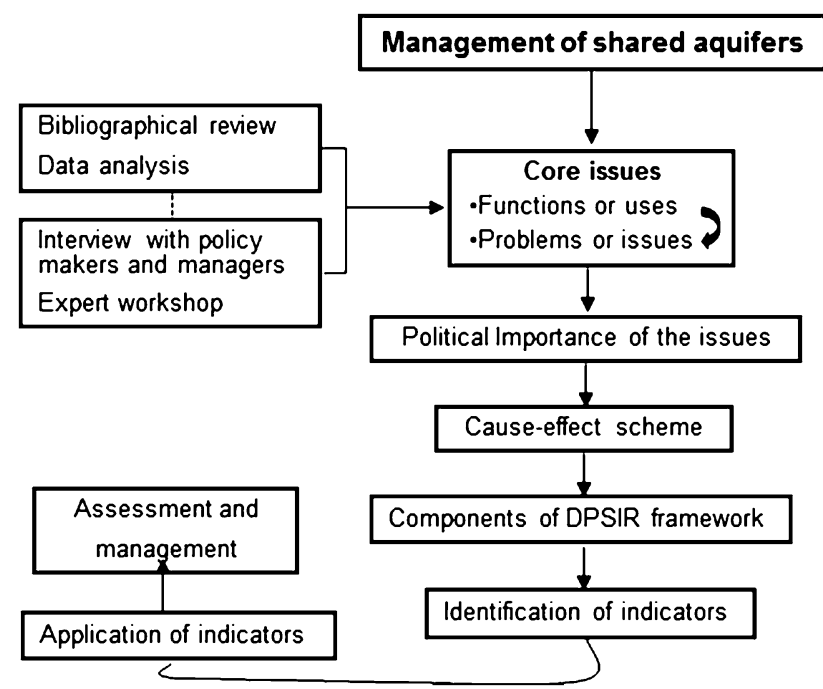

Fig. 2 Scheme of the approach applied to identify management issues and indicators for the aquifers supplying Mexico City

decision makers, and therefore at this stage designing and implementing the most effective policies based on reliable data is required.

In the following step, each problem related to groundwater use was analyzed and developed, describing the causality chain, into the different components of the DPSIR framework (Fig. 2): driving forces (human activities that cause problems), pressures (effort put into the function/use of aquifers), state (the condition of water systems in terms of concentrations or hydraulic characteristics), impacts (loss of the function/usage) and response (measures to face the problems). As an outcome of this analysis indicators associated with each component of the DPSIR framework are proposed.

To carry out this work, relevant bibliography and preexisting data were reviewed. This objective interpretation was then combined with practical and long-term management knowledge of a group of experts from the water sector (consultants and former CONAGUA officials) convened in a workshop. The goal of the workshop was both to discuss about core issues and to identify variables from the managers' viewpoint. The results were incorporated to the analysis.

\section{Results}

\section{Identification of management issues}

According to official information, more than $97 \%$ of all the water supplied to Mexico City from surface and groundwater sources is used for public consumption, $72 \%$ being supplied from shared aquifers. Given the significance of shared aquifers as a drinking water supply source, water supply is identified as the key issue in water management (Fig. 3).

The major problems affecting the use of aquifer systems as a source of drinking water are water level decline and groundwater pollution. Potentiometric level decline is a growing issue and it is widely recognized by water managers. Significant water level drawdown was observed in the regions where the PAI and Chiconautla system wells were drilled, as well as in the aquifers that supply the Lerma system and the ZMCM aquifer, whose regional drawdown has been studied by diverse authors (DGCOH 1994; Durazo and Farvolden 1989, and others).

Groundwater pollution is a problem reported more recently. In the study area, there are many factors that have influenced the presence of contaminants in groundwater. Areas highly vulnerable to contamination are located in mountains and foothills surrounding the valley, where high values of hydraulic conductivity of the underlying granular material and fractured volcanic rocks contribute to the infiltration of contaminants from the surface (Mazari and Mackay 1993). In addition, intensive groundwater extraction causes vertical migration of highly mineralized pore water from the overlying clay layers (aquitard) to the aquifers affecting their water quality. In addition, this process causes consolidation and cracking of the clay layers, which normally act as a pollutant barrier, leading to infiltration of pollutants into the aquifers (Durazo 1996). In some areas, changes in groundwater flow patterns due to intensive extraction have been reported as the cause of water quality degradation (AIC 1995). From the 1990s, these processes have affected the quality of groundwater to different degrees and, at present, contaminant concentrations exceed water quality standards at several locations. Water quality has been impacted in the southwestern areas of Mexico City, the PAI well fields in the north of the city, and the Lerma system well fields, in the Toluca Valley.

\section{Problem-oriented indicators}

Once the key issues affecting the groundwater sources that supply Mexico City were defined, the relations between driving forces, pressures, state, and impacts, as well as responses were identified (Fig. 3). From the developed DPSIR framework, parameters that could be measured to assess each of the problem components were proposed. Table 2 presents a set of 83 potential indicators grouped into driving forces, pressures, state, impacts and responses. Some details will be explored in the following sections.

\section{Driving forces}

The growth of Mexico City in recent decades has been extensively evaluated in the context of rapid urbanization 
Drinking Water Supply

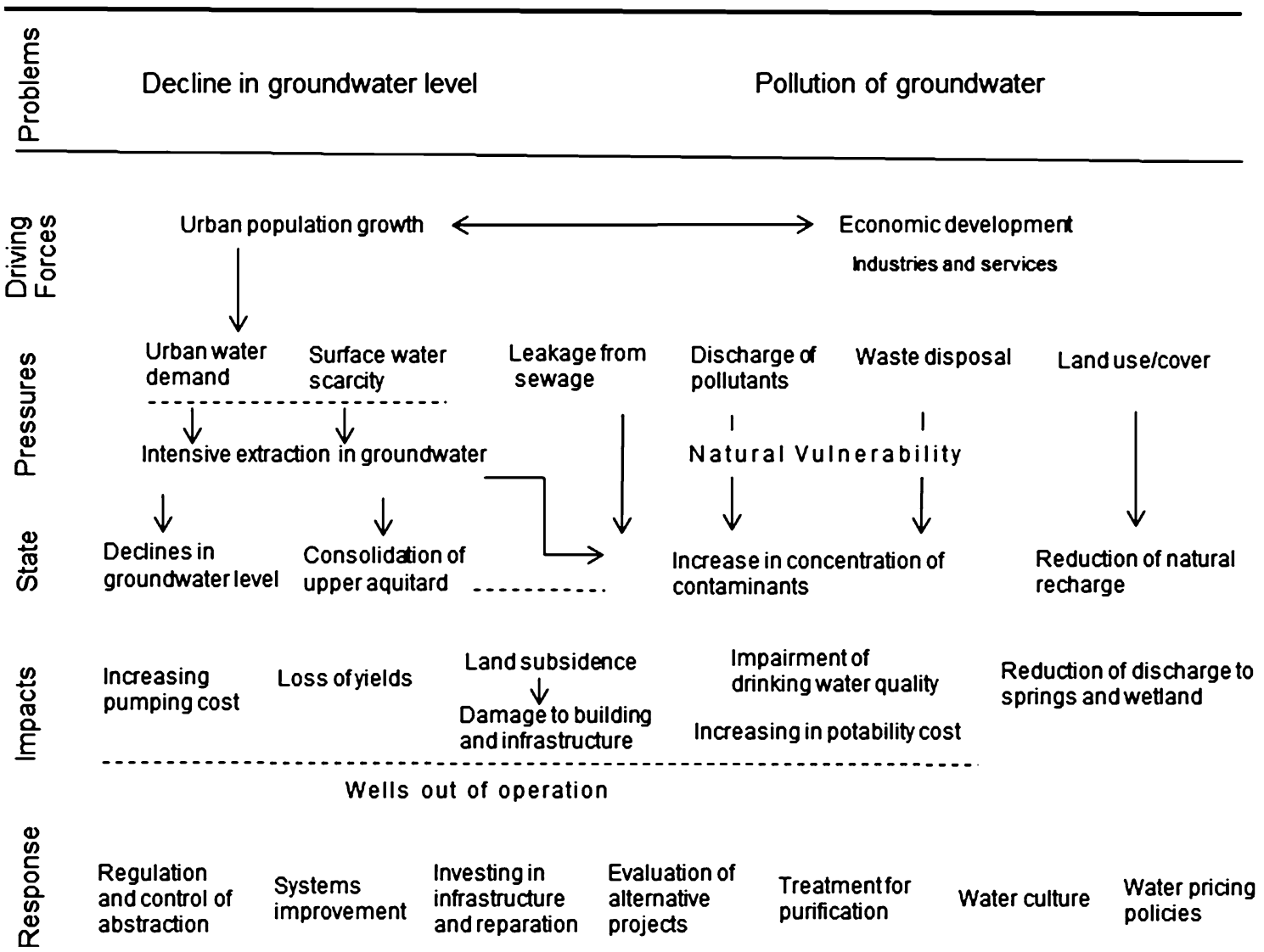

Fig. 3 DPSIR framework for the problems identified in aquifers supplying Mexico City

and creation of megacities in developing countries (Valladares and Prates 1995; Garza 1990). During the 1960s, Mexico City experienced significant changes not only due to population growth, but also due to accelerated urban and industrial development, which resulted in the expansion of settlements toward both the State of Mexico and the rural areas of Mexico City (PNUMA 2003). From 1950 to 2010, the population of Mexico City increased from 2.9 to 8.8 million and the number of houses was almost quadrupled while its Metropolitan Zone, that includes several municipalities of the State of Mexico, reached nearly 20 million inhabitants, becoming one of the largest urban conglomerates in the world. At present, the 8.8 million people living in Mexico City are distributed in 60,203 ha of urban areas and 88,442 ha of rural or conservation areas. Mexico City is one of the richest urban centers in the world contributing to approximately $20 \%$ of the national GDP. Clearly, the expanding population, as well as the rapidly increasing industry and services sector have been the driving forces behind urban water consumption. These driving forces can be measured, for example, by the evolution of the number of inhabitants in the areas of the exploited aquifers.

\section{Pressures}

Demographic growth and an expanding economy have made groundwater an essential component of the water supply in Mexico City. Groundwater can be quickly developed, close to the point-of-use, at relatively low capital cost. Water wells make water supply possible without the need for surface-water projects and ensure water is available at critical times of drought. Balances carried out in the study area estimate annual rates of withdrawal significantly higher than recharge rates (SACM 2009; CONAGUA 2002a, b). This mismatch has altered the natural condition of the groundwater systems leading to increasingly negative impacts in water quality and potentiometric level. For example, the relation between recharge and discharge is an indicator to assess pressures to the groundwater system.

Sanitation infrastructure needed to support development has failed to keep pace with the rapid growth of the city, principally in terms of investment and management. Untreated wastewater disposal and deficiencies of the drainage systems have become critical problems that affect 
Table 2 Indicators proposed for each component of the DPSIR framework and their definitions

\begin{tabular}{|c|c|c|}
\hline Type & Indicator & Definition \\
\hline \multirow[t]{5}{*}{$\begin{array}{l}\text { Driving } \\
\text { force }\end{array}$} & Number of inhabitants & $\begin{array}{l}\text { Temporal evolution of the number of inhabitants in delegations of Mexico City, } \\
\text { municipalities of the metropolitan area and municipalities over aquifers supplying } \\
\text { Mexico City }\end{array}$ \\
\hline & Number of houses & $\begin{array}{l}\text { Temporal evolution of the number of houses in delegations of Mexico City, } \\
\text { municipalities of the metropolitan area and municipalities over aquifers supplying } \\
\text { Mexico City }\end{array}$ \\
\hline & Population density & $\begin{array}{l}\text { Temporal evolution of the population density in delegations of Mexico City, } \\
\text { municipalities of the metropolitan area and municipalities over aquifers supplying } \\
\text { Mexico City }\end{array}$ \\
\hline & Urban development projects & $\begin{array}{l}\text { Spatial distribution of new urban development projects in Mexico City, municipalities } \\
\text { of the metropolitan area and municipalities over in aquifers supplying Mexico City }\end{array}$ \\
\hline & Number of industries & $\begin{array}{l}\text { Temporal evolution of the number of industries in delegations of Mexico City, } \\
\text { municipalities of the metropolitan area and municipalities over aquifers supplying } \\
\text { Mexico City }\end{array}$ \\
\hline
\end{tabular}

Electrical power sales

Number of service businesses

Evolution of the volume of electrical power sold to industries located in Mexico City, municipalities of the metropolitan area and municipalities over aquifers supplying Mexico City

Temporal evolution of the number of service businesses in delegations of Mexico City, municipalities of the metropolitan area and municipalities over aquifers supplying Mexico City

Economic activity

Contribution to Gross Domestic Product

Principal economic activities in delegations of Mexico City, municipalities of the metropolitan area and municipalities over aquifers supplying Mexico City

Temporal evolution of the contribution of Mexico City and Mexico State to the National Gross Domestic Product

Per capita Gross Domestic Product

Employed working population

Temporal evolution of the per capita Gross Domestic Product in Mexico City and Mexico State

Temporal evolution of the working population employed, per economic sector, in delegations of Mexico City, municipalities of the metropolitan area and municipalities over aquifers supplying Mexico City

Income of employed working population

Temporal evolution of income of the working population employed in delegations of Mexico City, municipalities of the metropolitan area and municipalities over aquifers supplying Mexico City

Change in land use

Human Development Index

Marginalization Index

Temporal and spatial evolution of land use in areas over aquifers supplying Mexico City

Temporal evolution of Human Development Index in delegations of Mexico City, municipalities of the metropolitan area and municipalities over aquifers supplying Mexico City

Temporal evolution of Marginalization Index in delegations of Mexico City, municipalities of the metropolitan area and municipalities over aquifers supplying Mexico City

Pressure Groundwater withdrawal for drinking water supply

Distribution of groundwater pumping for drinking water supply

Supply with surface water

Dam volumes

Temporal evolution of the groundwater volume withdrawn from the aquifers that supply Mexico City for drinking water purposes

Spatial distribution of groundwater pumping rates for drinking water production from the aquifers that supply Mexico City

Temporal evolution of the surface water volume supplied for drinking water in relation to total use in Mexico City

Temporal evolution of the water volume stored in dams supplying water to Mexico City

Precipitation in Cutzamala area

Groundwater withdrawal for industrial and service use

Distribution of groundwater pumping for industrial and service use

Groundwater availability

Evolution of the annual precipitation in catchment areas of the Cutzamala system

Temporal evolution of the groundwater volume withdrawn from the aquifers that supply Mexico City for industrial and service use

Spatial distribution of groundwater pumping rates for industrial and service use in the aquifers that supply Mexico City

Relation between recharge and discharge rates in the aquifers that supply Mexico City 
Table 2 continued

\begin{tabular}{|c|c|c|}
\hline Type & Indicator & Definition \\
\hline & Water available per capita & $\begin{array}{l}\text { Availability of renewable water resources per capita in each aquifer area or } \\
\text { hydrologic region }\end{array}$ \\
\hline & Supply sources & $\begin{array}{l}\text { Supply source (or system) per delegation or municipality, over aquifers supplying } \\
\text { Mexico City }\end{array}$ \\
\hline & $\begin{array}{l}\text { Number of connections to the drinking water } \\
\text { service }\end{array}$ & $\begin{array}{l}\text { Temporal evolution of the number of connections to the drinking water service in } \\
\text { delegations of Mexico City, municipalities of the metropolitan area and } \\
\text { municipalities over aquifers supplying Mexico City }\end{array}$ \\
\hline & $\begin{array}{l}\text { Number of houses without drinking water } \\
\text { service }\end{array}$ & $\begin{array}{l}\text { Temporal evolution of the number of houses without drinking water service in } \\
\text { delegations of Mexico City, municipalities of the metropolitan area and } \\
\text { municipalities over aquifers supplying Mexico City }\end{array}$ \\
\hline & Number of houses without sewerage & $\begin{array}{l}\text { Temporal evolution of the number of houses without sewerage in delegations of } \\
\text { Mexico City, and municipalities over aquifers supplying Mexico City }\end{array}$ \\
\hline & Discharge by industries & $\begin{array}{l}\text { Spatial distribution of industry discharge sites in delegations of Mexico City, and } \\
\text { municipalities over aquifers supplying Mexico City }\end{array}$ \\
\hline & Unplanned settlements in conservation areas & $\begin{array}{l}\text { Temporal and spatial distribution of unplanned settlements in conservation areas in } \\
\text { Mexico City and municipalities over aquifers supplying Mexico City }\end{array}$ \\
\hline & Unplanned waste disposal sites & $\begin{array}{l}\text { Temporal evolution and spatial distribution of unplanned waste disposal sites in } \\
\text { Mexico City and municipalities over aquifers supplying Mexico City }\end{array}$ \\
\hline & Treated wastewater & $\begin{array}{l}\text { Treated wastewater volume per capita in Mexico City and municipalities over } \\
\text { aquifers supplying Mexico City }\end{array}$ \\
\hline & Groundwater vulnerability & $\begin{array}{l}\text { Spatial distribution of natural groundwater vulnerability—as a function of the } \\
\text { characteristics of the aquifer, the unsaturated geological material and the overlying } \\
\text { soil—in aquifers supplying Mexico City }\end{array}$ \\
\hline & Relative water stress index & Relation between water consumptive use and water renewable resources \\
\hline & Treated wastewater reuse & $\begin{array}{l}\text { Treated wastewater volume that is reused in Mexico City and municipalities over } \\
\text { aquifers supplying Mexico City }\end{array}$ \\
\hline \multirow[t]{13}{*}{ State } & Groundwater level & $\begin{array}{l}\text { Temporal and spatial evolution of the groundwater level in aquifers supplying } \\
\text { Mexico City }\end{array}$ \\
\hline & Average groundwater level decline & $\begin{array}{l}\text { Spatial distribution of average groundwater level decline rates in aquifers supplying } \\
\text { Mexico City }\end{array}$ \\
\hline & Areas showing groundwater level decline & $\begin{array}{l}\text { Area percentage showing groundwater level decline in relation to the total area of } \\
\text { each aquifer }\end{array}$ \\
\hline & Wells showing groundwater level decline & $\begin{array}{l}\text { Temporal evolution of the number of wells with problems associated with } \\
\text { groundwater level decline }\end{array}$ \\
\hline & $\begin{array}{l}\text { Areas presenting natural groundwater quality } \\
\text { changes }\end{array}$ & $\begin{array}{l}\text { Area percentage showing natural groundwater quality changes in relation to the total } \\
\text { area of each aquifer }\end{array}$ \\
\hline & Wells presenting quality changes & Temporal evolution of the number of wells presenting water quality changes \\
\hline & Iron concentration & $\begin{array}{l}\text { Temporal and spatial evolution of iron concentration in aquifers supplying Mexico } \\
\text { City }\end{array}$ \\
\hline & Manganese concentration & $\begin{array}{l}\text { Temporal and spatial evolution of manganese concentration in aquifers supplying } \\
\text { Mexico City }\end{array}$ \\
\hline & Sodium concentration & $\begin{array}{l}\text { Temporal and spatial evolution of sodium concentration in aquifers supplying } \\
\text { Mexico City }\end{array}$ \\
\hline & $\begin{array}{l}\text { Areas with anthropogenic contamination } \\
\text { problems }\end{array}$ & $\begin{array}{l}\text { Area percentage with anthropogenic contamination problems in relation to the total } \\
\text { area of each aquifer }\end{array}$ \\
\hline & Nitrate concentration & $\begin{array}{l}\text { Temporal and spatial evolution of nitrate concentration in aquifers supplying Mexico } \\
\text { City }\end{array}$ \\
\hline & Chloride concentration & $\begin{array}{l}\text { Temporal and spatial evolution of chloride concentration in aquifers supplying } \\
\text { Mexico City }\end{array}$ \\
\hline & Evolution of electrical conductivity & $\begin{array}{l}\text { Temporal and spatial evolution of electrical conductivity in aquifers supplying } \\
\text { Mexico City }\end{array}$ \\
\hline
\end{tabular}


Table 2 continued

\begin{tabular}{|c|c|c|}
\hline Type & Indicator & Definition \\
\hline \multirow[t]{18}{*}{ Impact } & Land subsidence rates & $\begin{array}{l}\text { Temporal and spatial evolution of land subsidence rates in areas over aquifers } \\
\text { supplying Mexico City }\end{array}$ \\
\hline & Damage costs & Costs of damage to infrastructure and buildings due to land subsidence \\
\hline & Cost of infrastructure repair & Cost of repairing infrastructure damaged by land subsidence \\
\hline & Wells affected by level decline & $\begin{array}{l}\text { Temporal and spatial evolution of the number of wells affected (stopped, repaired) } \\
\text { by groundwater level decline in each system }\end{array}$ \\
\hline & Water volume & $\begin{array}{l}\text { Temporal evolution of water volume produced and supplied per system and well } \\
\text { field }\end{array}$ \\
\hline & Water dotation & $\begin{array}{l}\text { Distribution of water dotation to houses connected to the drinking water service in } \\
\text { delegations of Mexico City and municipalities over aquifers supplying Mexico } \\
\text { City }\end{array}$ \\
\hline & Power consumed & $\begin{array}{l}\text { Temporal evolution of the power consumed in the operation of each system and well } \\
\text { field }\end{array}$ \\
\hline & Maintenance and Operation costs & $\begin{array}{l}\text { Temporal evolution of maintenance and operation costs for each system and well } \\
\text { field }\end{array}$ \\
\hline & Production costs & $\begin{array}{l}\text { Temporal evolution of water production costs per cubic meter in each system and } \\
\text { well field }\end{array}$ \\
\hline & Wells affected by quality change & $\begin{array}{l}\text { Temporal and spatial evolution of the number of wells affected (stopped, re- } \\
\text { localized, connected to treatment plant) by water quality changes in each system } \\
\text { and well field }\end{array}$ \\
\hline & Wells exceeding quality standards & $\begin{array}{l}\text { Temporal and spatial evolution of the number of wells exceeding drinking water } \\
\text { standards (for one or more parameters) }\end{array}$ \\
\hline & Groundwater requiring purification & $\begin{array}{l}\text { Temporal evolution of the groundwater volume supplied by the systems and well } \\
\text { fields that require purification }\end{array}$ \\
\hline & Days without service & $\begin{array}{l}\text { Number of days without drinking water service in delegations of Mexico City and } \\
\text { municipalities over aquifers supplying Mexico City }\end{array}$ \\
\hline & Water supplied by tanker trucks & $\begin{array}{l}\text { Volume of water supplied by tanker trucks in delegations of Mexico City and } \\
\text { municipalities over aquifers supplying Mexico City }\end{array}$ \\
\hline & Spring flow & Evolution of spring water volume in the area \\
\hline & Springs disappearance & Temporal evolution of the number of springs that disappear \\
\hline & Change in base flow & Number of wetlands and lagoons affected by changes in base flow \\
\hline & Pollution events & Number of drinking water pollution events reported by different means \\
\hline \multirow[t]{12}{*}{ Response } & Water levies records & $\begin{array}{l}\text { Evolution of the number of water levies records (per use type) in the area of aquifers } \\
\text { that supply Mexico City }\end{array}$ \\
\hline & Water volume concessioned & $\begin{array}{l}\text { Evolution of volume of groundwater and surface water, concessioned in the area of } \\
\text { aquifers that supply Mexico City, and registered in the REPDA (Registro Publico } \\
\text { de Derechos de Agua, Water Rights Public Record) }\end{array}$ \\
\hline & Number of water harvesting sites & $\begin{array}{l}\text { Evolution of the number of water harvesting sites registered (per use type) in the area } \\
\text { of aquifers that supply Mexico City }\end{array}$ \\
\hline & Transfer of water levies & $\begin{array}{l}\text { Evolution of water levies transfer (per use type) in the area of aquifers that supply } \\
\text { Mexico City }\end{array}$ \\
\hline & Legislation changes & $\begin{array}{l}\text { Changes in laws, regulations, restrictions and other legal instruments related to water } \\
\text { management }\end{array}$ \\
\hline & Infrastructure investment & Evolution of the investment in new infrastructure for water supply \\
\hline & Repair expenditures & Evolution of expenditures for damaged infrastructure repair \\
\hline & Wells drilled & $\begin{array}{l}\text { Evolution of the number of wells drilled to reposition affected wells or to increase } \\
\text { the water supply }\end{array}$ \\
\hline & Supply increase & $\begin{array}{l}\text { Increase in the water supply compared to the previous period in delegations of } \\
\text { Mexico City and municipalities over aquifers supplying Mexico City }\end{array}$ \\
\hline & System improvement & Evolution of the number of actions undertaken to improve the distribution system \\
\hline & Water service revenue & Evolution of the drinking water service revenue accrued by SACM \\
\hline & Water tariff & Evolution of the water tariff in the area supplying the SACM \\
\hline
\end{tabular}


Table 2 continued

\begin{tabular}{|c|c|c|}
\hline Type & Indicator & Definition \\
\hline & Urbanization control & $\begin{array}{l}\text { Evolution of the number of actions undertaken to control urbanization in rural and } \\
\text { conservation areas }\end{array}$ \\
\hline & Purification capacity & Evolution of the installed capacity for purification to drinking water standards \\
\hline & Purified water volume & Temporal evolution of the volume of water that is purified for drinking water purposes \\
\hline & Water culture & Evolution of the number of actions implemented in the framework of water culture \\
\hline
\end{tabular}

groundwater quality. In some places, domestic and industrial wastewater infiltrates directly into the ground creating a potential groundwater contamination threat. This threat is exacerbated by the sprawl of urban settlements in the highlands and piedmont areas (mostly defined as conservation areas under the Urban Development Act) where groundwater recharge takes place (Sánchez Barrientos 2005; Carrera-Hernández and Gaskin 2008) and is highly vulnerable to contamination (Vázquez 1995). In the period 1980-2000, 76 \% of the new houses built in Mexico City (377,000 units) were located in the seven municipalities that contain the majority of the conservation area (Tortajada 2006). A large number of these settlements, especially in the southern part of the city, have septic tanks due to the difficulty and elevated costs of building infrastructure on the volcanic rock substrate predominant in these areas. At the same time, old quarries and sand mines located in these highland areas are often used as waste disposal sites, increasing the hazard of groundwater contamination with trace elements and organic compounds.

\section{State}

The pressures from groundwater extraction, the discharge of pollutants and urban sprawl have changed the prevailing hydrogeological regime and water quality. There is wide evidence of the regional drawdown in the groundwater potentiometric level caused by the intensive extraction from the shared aquifers (SACM 2007; CONAGUA 2007a). Based on records of potentiometric groundwater level from 1969, the average rate of drawdown is estimated at $1 \mathrm{~m} /$ year and reaches a maximum value of nearly $2.5 \mathrm{~m} /$ year in the north of the city, where the Chiconautla system and three well fields of the PAI system are located (Carrera-Hernández and Gaskin 2007). Evolution of the groundwater level is a useful indicator to evaluate the state of groundwater resources.

In some areas, intensive groundwater extraction has induced flow from the upper aquitard clay layers causing depressurization and consolidation of these materials. Where pumping has disturbed the groundwater flow pattern, different elements such as manganese, iron, strontium, barium, chloride and sodium, have been introduced to the water supply of Mexico City and its Metropolitan Zone (SMA 1999; Edmunds et al. 2002; Huizar-Alvarez et al. 2004). The increase in manganese and iron concentrations has been associated with the mobilization of water from the overlying clay, while the induction of vertical flows and flow from natural discharge zones are reported as the major cause of increasing concentrations of chloride and sodium.

Changes in the abstracted water quality that indicate anthropogenic pollution have been exposed in numerous studies (CONAGUA 2001, 2007a). Concentrations of ammonia nitrogen, microorganisms and trace metals, among others, exceeding the Mexican Health Agency maximum contaminant level were determined in domestic water supply wells located in the study area. For example, some wells supplying southern Mexico City are thought to be contaminated by leachates from the Santa Catarina waste disposal site, with electrical conductivity measured as high as $7640 \mu \mathrm{S}$ (Paz-Becerril 1991).

Some authors report there has been a reduction in potential groundwater recharge due to changes in land cover in the area of Mexico City (AIC 1995; Sánchez Barrientos 2005), nevertheless, determinations on the basis of quantitative analysis are scarce. Carrera-Hernández and Gaskin (2008) estimated the recharge rate in the ZMCM area (excluding the area covered by the aquitard because this unit is considered to be impermeable) using a daily soil water balance based on climatological variables in 1981 and the urban cover in 1981 and 1985. They estimated the recharge flow in the alluvial plain for $1981\left(1.9 \mathrm{~m}^{3} / \mathrm{s}\right)$ and found almost a $20 \%$ decline (to $1.6 \mathrm{~m}^{3} / \mathrm{s}$ ) when considering the urban area in 1985.

\section{Impacts}

The pressures on the groundwater systems produce serious water supply inefficiencies that affect the service, and constrain the future supply. Land subsidence has been consistently documented as an impact of intensive groundwater extraction, which induces flows from the upper aquitard and causes the consolidation of these materials (Figueroa-Vega 1984; Cruickshank-Villanueva 1984; Rivera et al. 1991; González-Morán et al. 1999; 
Birkle et al. 1998). The subsidence accumulated over the last 100 years has reached more than $7.5 \mathrm{~m}$ in downtown and more than $15 \mathrm{~m}$ in some areas subject to more intense groundwater extraction and/or having thicker clay layers. These subsidence rates have caused extensive damage to the water supply, sewerage and stormwater infrastructure, increasing networks leakage, causing the loss of supply wells and flooding due to inversion of the land slope. The average land subsidence rate for different areas can be a useful impact indicator.

Another impact associated with intensive groundwater extraction is the reduction in drinking water quality due to the mobilization of lower quality water over large areas. Additional causes of groundwater water quality degradation are contamination from improper waste disposal practices and network leakage. In some wells, drinking water quality impairment has forced the installation of a purification plant at the wellhead. The volume of groundwater that requires purification is a useful indicator to assess this impact.

The continuous drop in the water level has prompted the installation of deeper wells that require more energy to overcome the pumping lift. In many cases, the premature obsolescence of wells has required drilling new ones and consequently, high financial costs have been incurred to maintain the water supply.

Groundwater yield loss is another impact observed. For example, in a 6-year period in the PAI system, performance declined $20 \%$ in the "Los Reyes-Ecatepec" well field, and $50 \%$ in the "Mixquic-Santa Catarina" well field (CONAGUA 2007b). The magnitude of the impacts can be measured also by the number of wells out of operation either due to high concentrations of trace elements, decline in groundwater level or as a measure to stop land subsidence. As many as 86 wells were reported out of operation in the SACM by 2008 , while 72 wells were relocated in the period 2006-2008. In the Lerma system, the number of wells out of service grew from 8 in 1997 to 39 in 2008.

Impacts on groundwater discharge flows have been exposed by Durazo and Farvolden (1989), who attributed the reduction of groundwater discharge into wetlands and springs of the Xochimilco area, in the south of Mexico City, to the intensive groundwater withdrawal.

\section{Management policy as response}

While water management policies are possible at all levels in the DPSIR framework, in Mexico it has been principally linked with the task of supplying water to the public and sustaining economic activities under an engineering approach. Facilitated by centralized water management, large-scale supply systems as traditionally performed and other solutions of minor scale have been planned, financed and operated by the CONAGUA to cope with the water supply crisis.

To prevent the overuse of aquifers, protect the drinking water supply and preserve and control the water quality, in 1992 various amendments were introduced to the Federal Water Law. According to these, CONAGUA established prohibitions for new groundwater extractions and regulations for water access, creating the use rights market and incorporating the estimation of reserves of the country's main aquifers (Escolero and Martinez 2007). Based on these estimations in the area of the aquifers supplying Mexico City, there is no water available to support additional withdrawal, and therefore the access to water has been restricted to water rights transfers that mostly take place when small farmers, often farmers in communal use lands, sell their water rights to industries or cities.

Drinking water quality impairment is becoming a more significant concern than quantity in some areas. To produce water that satisfies Mexican quality standards, some wells have been abandoned while in other wells, on-site purification plants have been installed. At some locations, the capacity and design of these plants is resulting insufficient due to continuously changing concentrations and the occurrence of new elements affecting water quality. This is particularly noticeable in areas such as Iztapalapa, Xochimilco, and Tláhuac.

Water supply has been identified by the authorities as one of the most critical hurdles to reach sustainability in Mexico City. The Worldbank (2013) predict that water demand of the Mexico City Metropolitan Area will grow by $28 \%$ in 2030 , generating a deficit of $25 \mathrm{~m}^{3} / \mathrm{s}$, or up to $46 \mathrm{~m}^{3} / \mathrm{s}$ when taking current overexploitation into account. Until recently, the major contributions to close the gap had been projected to come from infrastructure projects that import surface water from external basins. The Temascaltepec project is the expansion of the Cutzamala system to increase the flow of transferred water to $24 \mathrm{~m}^{3} / \mathrm{s}$. Three other projects refer to similarly large water transfers from the Amacuzac, Tecolutla and Atoyac rivers (CONAGUA 2007c).

However, with the global paradigm shifts, water management exceeds the task of water supply as traditionally performed and instead calls for a set of diverse solutions integrating demand and supply management in fit-forpurpose schemes (Wolf et al. 2006; Martinez et al. 2011, Bahri 2012). In accordance, some changes were made within the most recent planning exercise in 2012, the Regional Water Program 2030 (CONAGUA 2012). This program foresees increasing water availability not only relying on large import systems, but also incorporating additional water from the potabilization of the scarce surface water in the city, re-importing groundwater from the Mezquital and Tula valleys, and recharging groundwater 
with treated sewage and stormwater as a measure to restore the aquifers. To manage demand, a set of technical solutions are proposed aiming at achieving household water savings and reducing systems leakage.

Non-structural measures such as increases in the water tariff and actions to promote payment of services have been introduced, also partly to generate public awareness about the relative scarcity of the water resources. Based on the premise that water tariffs should reflect at least the service costs, the SACM applies a development index to calculate differentiated water tariffs based on the socio-territorial characteristics considering social development, wealth and income. Thus, the local government aims to encourage water conservation and protect the poorer sectors.

Sufficient funding must be provided according to the developed strategies. Since 1996, the mechanisms have been established for the states and federal government to allocate funds for the construction of hydraulic infrastructure in the Basin of Mexico (Fideicomiso 1928) and to support programs, projects and actions related to environment, water, sanitation, social infrastructure, and urban development among others, in the Metropolitan Area of Mexico City (Fideicomiso F685).

Important advances are made in the development of technical strategies and legal instruments to support water supply sustainability. However, these must be implemented considering competing stakeholder interests. Consequently, the success of water management requires inter-sectoral coordination and communication to enhance the efficiency of the interventions.

\section{Discussion}

The global paradigm shifts promote a more integrated policy making process that takes into account inter-sectoral policy coordination and stakeholder participation (Luzi 2010). In this context, Mexico has initiated actions that will lead to a transition from policies being set by CONAGUA as the sole decision makers to a more decentralized water management scheme. However, conflicts of interests, divergence of opinion regarding the issues and the ways to approach them, topped with the pressure to resolve the urgent problems impede this transition.

The transboundary character of groundwater supplying Mexico City and the existence of multiple stakeholders relying on groundwater around and in the City promote the question of how these shared aquifers can be more effectively managed. To this end, suitable methodological approaches can contribute to bring together views and strategies and to assist decision makers and planners in water agencies and those who are involved in the development of sustainable water management schemes. Such approaches have been promoted by international agencies to support governments in management of transboundary water resources; however, this has been scarcely tested in aquifers shared within the same country.

In this work, an approach proposed by the UN/ECE was applied to the City of Mexico and indicators were developed from the relevant problems. The proposed indicators, as opposed to specific indicators such as groundwater resources sustainability indicators developed by the UNESCO/IAEA/IAH Working Group, (UNESCO 2007; Vrba et al. 2006), were developed in a comprehensive framework considering local issues and the available information as well as information that is yet to be obtained. This contributes to their acceptance and implementation, while encouraging more effective communication between stakeholders such as policy makers, managers, scientists and the public.

The indicators identified from the applied methodological approach are proposed as a first step, more accurate tools can be incorporated later on. The strategy should focus on adopting a limited set of variables for each DPSIR component, using the available data, while efforts are taken to generate and collect additional data to assist in the formulation of new relevant variables.

Depending on the type, selecting a variable presents different degrees of difficulty. Drivers and pressure variables which are related to the socioeconomic system are available in databases at the National Institute of Statistics and Geography (Instituto Nacional de Estadística y Geografía, INEGI). This type of data has been surveyed in a standardized manner, at different local and regional scales, which makes it easy to interpret and use. The main information demands are associated with indicators of pressure, state and impacts related to the natural system. Existing data from different agencies must be processed under a standardized approach for ease of use. Data gaps may constrain the adoption of certain indicators, therefore concerted efforts must be made to collect and standardize the missing data, at the required spatial and temporal scales. When data are not yet available for calculating an indicator, its estimation can be qualitative, which in turn reinforces the need for data collection for a more precise formulation.

Development of databases and indicators are interlinked and interdependent activities. Proper data management routines can convert technical data into valuable information for decision makers, politicians and ultimately, resource users. Therefore, the information collected and the data produced by monitoring programs should be adequately stored and organized, assuring it is easily accessible. Establishing interagency agreements to foster the distribution and exchange of information is an essential step in the process of cooperation, to support policy making and management of groundwater resources. 
The problems affecting water supply in Mexico City have reached a high level on the political agenda. Thus, more precise data and operational indicators are now needed to effectively design and implement management measures and evaluate their performance. Funding must be provided to improve monitoring and evaluation programs designed to fill gaps in the current groundwater knowledge and to maintain a robust database, in the context of water policy and management programs. The convoluted nature of political roles and responsibilities of the agencies managing the water supply in Mexico City has been an obstacle to develop coordinated action. Implementation of new approaches from the shared resources perspective and the development of common management tools will require negotiation and adaptation to provide the solutions to the water supply problems that the Mexico City society demands.

\section{Conclusions}

A methodological scheme integrating the concepts of usesproblems and the policy life cycle, with the DPSIR framework was used to identify key issues and to select indicators tailored to the local problems associated with managing groundwater resources supplying Mexico City. The proposed framework seems to be appropriate to support cooperation between the agencies responsible for management and development of the shared aquifers. The DPSIR methodology helped to explore and analyze, in a simplified manner, the relationships between the sources and outcomes of groundwater problems and, at the same time, helped to understand their dynamic. Thus, each issue describing the causality chain, from driving forces to impacts and response, could be represented by a linked variable.

Indicators are a useful tool for policy makers and managers because they provide simplified information of the current status and future trends of the systems, and can guide the formulation and evaluation of management policies. Implementation of indicators and other management tools in Mexico City will require water agencies to generate and exchange information, learning to coordinate actions and working together to face the water challenges that lie ahead.

Acknowledgments The authors appreciate support received from the Federal District Institute of Science and Technology (Instituto de Ciencia y Tecnología del Distrito Federal, ICyTDF). Also to the support received of the project 155039 CB-CONACYT. Special thanks go to UNESCO's International Hydrological Programme (IHP UNESCO), Montevideo Office, for their collaboration.

\section{References}

AIC (1995) El agua y la ciudad de México. Academia de la Investigación Científica, Academia Nacional de Ingeniería, Academia Nacional de Medicina, Mexico City

Bahri A (2012) Integrated Urban Water Management. GWP Tec background papers. Global Water Partnership, Stockholm, p 16

Birkle P, Torres-Rodriguez V, González-Partida E (1998) The water balance for the Basin of the Valley of Mexico and implications for future water consumption. Hydrogeol J 6:500-517

Carrera-Hernández JJ, Gaskin SJ (2007) The Basin of Mexico aquifer system: regional groundwater level dynamics and database development. Hydrogeol J 15:1577-1590

Carrera-Hernández JJ, Gaskin SJ (2008) Spatio-temporal analysis of potential aquifer recharge: application to the Basin of Mexico. J Hydrol 353:228-246

CONAGUA (2001) Estudio para actualizar los datos constructivos de los equipos instalados en los pozos de la Cuenca del Valle de México, pertenecientes al sistema hidráulico del D.F. Ariel Consultores, Comisión Nacional del Agua. Mexico City

CONAGUA (2002a) Determinación de la disponibilidad de agua en el acuífero Zona Metropolitana de la Ciudad de México. Subgerencia de Evaluación y Modelación Hidrogeológica, Comisión Nacional del Agua, Mexico City

CONAGUA (2002b) Determinación de la disponibilidad de agua en el acuífero Cuautitlán-Pachuca, Estado de México e Hidalgo. Subgerencia de Evaluación y Modelación Hidrogeológica, Comisión Nacional del Agua, Mexico City

CONAGUA (2007a) Plan de Acción Inmediata. Organismo de Cuenca Aguas del Valle de Mexico, Comisión Nacional del Agua, Mexico City

CONAGUA (2007b) Sistema hidrológico del Valle de México. Organismo de Cuenca Aguas del Valle de México, Comisión Nacional del Agua, Mexico City

CONAGUA (2007c) Programa de Sustentabilidad Hídrica de la Cuenca del Valle de México. Comisión Nacional del Agua, Mexico City

CONAGUA (2009) Estadísticas de la Región Hidrológica Administrativa XIII. Aguas del Valle de México, Comisión Nacional del Agua, Mexico City

CONAGUA (2012) Programa Hídrico Regional Visión 2030. Región Hidrológico-Administrativa XIII Aguas del Valle de México, Comisión Nacional del Agua, Mexico City

Cruickshank-Villanueva C (1984) Numerical simulation of subsidence due to pumping with hysteresis. In: Johnson AI, Carbognin L, Ubertini L (eds) Third international symposium on land subsidence. IAHS, Venice

DGCOH (1994) Diagnostico del estado presente de las aguas subterráneas de la Ciudad de México y determinación de sus condiciones futuras. Instituto de Geofísica UNAM, Dirección General de Construcción y Operación Hidráulica, Mexico City

Durazo J (1996) Ciudad de México. Acuitardo superficial y contaminación acuífera. Ingeniería Hidráulica en México XI 2:5-14

Durazo J, Farvolden R (1989) The groundwater regime of the Valley of Mexico from historic evidence and field observations. J Hydrol 112:171-190

Edmunds WM, Carrillo-Rivera JJ, Cardona A (2002) Geochemical evolution of groundwater beneath Mexico city. J Hydrol 258:1-24

Escolero O, Martinez S (2007) The Mexican experience with groundwater management. In: Ragone $\mathrm{S}$, de la Hera $\mathrm{A}$, Hernandez-Mora N (eds) The Global Importance of Groundwater in the 21st Century. NGWA Press, Westerville 
Figueroa-Vega G (1984) Case story no. 9.8. Mexico DF, Mexico. In: Guidebook to studies of land subsidence due to groundwater withdrawal, UNESCO, Paris

Garza G (1990) El carácter metropolitano de la urbanización en México, 1900-1988. Estudios Demográficos y Urbanos, 5(1), Ene./Abr., Mexico

Godfrey L, Claassen M, Todd C, Smakhtin V, du Preez M, Stassen R (2002) National core set of environmental indicators. Phase 3, selection of indicators inland waters. In: National Environmental Indicators Programme for State of Environment Reporting in South Africa. Specialist Report 3, vol 1

González-Morán T, Rodríguez R, Cortes SA (1999) The Basin of Mexico and its metropolitan area: water abstraction and related environmental problems. J South Am Earth Sci 12(6):607-613

Huizar-Alvarez R, Carrillo-Rivera JJ, Hergt T, Angeles-Serrano G, Cardona A (2004) Chemical response to groundwater extraction southeast of Mexico City. Hydrogeol J 12(4):436-450

Karageorgis AP, Kapsimalis V, Kontogianni A, Skourtos M, Turner KR, Salomons W (2006) Impact of 100-Year Human interventions on the deltaic coastal zone of the inner Thermaikos Gulf (Greece): a DPSIR framework analysis. Environ Manag 38(2):304-315

Luzi S (2010) Driving forces and patterns of water policy making in Egypt. Water Policy 12:92-113

Martinez SE, Escolero O, Wolf L (2011) Total urban water cycle models in semiarid environments - quantitative scenario analysis at the area of San Luis Potosi, Mexico. Water Resour Manage 25:239-263. doi:10.1007/s11269-010-9697-6

Mazari M, Mackay MD (1993) Potential groundwater contamination by organic compounds in the Mexico City Metropolitan area. Environ Sci Technol 27:794-802

Ojeda-Martınez C, Gimenez Casalduero F, Bayle-Sempere JT, Barbera Cebrian C, Valle C, Sanchez-Lizaso JL, Brito A (2009) A conceptual framework for the integral management of marine protected areas. Ocean Coastal Manag 52:89-101

Paz-Becerril JA (1991) Efecto del tiradero de basura de Santa Fe Catarina en pozos de agua potable In: 1er Congreso Nacional de residuos sólidos peligrosos: recurso o desperdicio? Asociación Mexicana Control de Residuos Sólidos y Peligrosos, Mexico City

PNUMA Gobierno del Distrito Federal and Centro de Investigaciones en Geografía y Geomática Ing. Jorge L. Tamayo A.C. (2003) Una visión del sistema urbano ambiental, GEO, Mexico City

Rivera A, Ledoux E, de Marsily G (1991) Nonlinear modeling of groundwater flow and total subsidence of the Mexico City aquifer-aquitard system. In: Singh B, Saxena NC (eds) Fourth international symposium on land subsidence. Balkema, Rotterdam

Rodríguez-Ortega C, Flores-Martínez A (2009) El sistema nacional de indicadores ambientales. In: López BJ, Rodríguez ML (eds) Desarrollo de indicadores ambientales y de sustentabilidad en México. Instituto de Geografía UNAM, Mexico City

SACM (2007) Estudio de los niveles estáticos y dinámicos de los acuíferos del Valle de Toluca para la interpretación del abatimiento que han presentado los acuíferos del Valle de
Toluca, Ixtlahuaca-Atlacomulco en los últimos 50 años. Asteroide SA de CV, Sistema de Agua de la Ciudad de Mexico, Mexico City

SACM (2009) Estudio de la medición de niveles del agua subterránea en los Valles de Toluca e Ixtlahuaca en el Alto Lerma. Capítulo V Balance. Departamento de Geohidrología, Sistema de Agua de la Ciudad de Mexico, Mexico City

Sánchez Barrientos ED (2005) La Expansión Urbana en Suelo de Conservación, Asentamientos Humanos Irregulares. In: Primer Congreso Nacional de Suelo Urbano 2005. http://www.metro poli.org.mx/htm/areas/0/sanchez_barrientos.pdf. Accessed 27 Jan 2010

SEMARNAT (2000) Indicadores para la evaluación del desempeño ambiental. Instituto Nacional de Ecologia, Secretaria de Medio ambiente y Recursos Naturales, Mexico City

SMA (1999) Definición del control de la calidad del agua subterránea extraída de la subcuenca de México. Delegación Ixtapalapa, Instituto de Geologia UNAM, Secretaria del Medio Ambiente, Mexico City

Sophocleous M (2010) Review: groundwater management practices, challenges, and innovations in the High Plains aquifer, USAlessons and recommended actions. Hydrogeol J 18:559-575

Tortajada C (2006) Water management in Mexico City Metropolitan Area. Int J Water Resour Dev 22(2):353-376

UN/ECE (1999) Problem-oriented approach and the use of indicators, KIWA NV vol 2, Lelystad, The Netherlands

UN/ECE (2000) Guideline on monitoring and assessment of transboundary groundwaters. UN/ECE Task Force on Monitoring and Assessment, Lelystad

UNESCO (2007) Groundwater resources sustainability indicators, Vrba J, Lipponen A (eds) IHP-VI, series on groundwater No. 14

Valladares L, Prates C (1995) La investigación urbana en América Latina. Tendencias actuales y recomendaciones. In: Gestión de las transformaciones sociales MOST. Documento de debate $\mathrm{N}^{\circ} 4$. UNESCO. http://www.unesco.org/most/vallspa.htm. Accessed 10 Feb 2010

Vázquez SE (1995) Modelo conceptual hidrogeológico y características hidráulicas del acuífero en explotación en la parte meridional del Cuenca de México. Thesis, Universidad Nacional Autónoma de México, Mexico

Vrba J, Hirata R, Girman J, Haie N, Lipponen A, Neupane B, Wallin B (2006) Groundwater resources sustainability indicators. In: Proceeding international symposium on groundwater sustainability (ISGWAS), Alicante, Spain. http://aguas.igme.es/igme/ ISGWAS/Ponencias\%20ISGWAS/3-Vrba.pdf. Accessed 10 Feb 2010

Wolf L, Morris BL, Burn S, Hötzl H (2006) The AISUWRS approach. In: Wolf L, Morris B, Burn S (eds) Urban water resources toolbox-integrating groundwater into urban water management. IWA, London, p 296

Worldbank (2013) Urban water in the valley of Mexico: a green path for tomorrow. Mexico City, p 92. http://www.worldbank.org/ laciuwm. Accessed 01 July 2013 